\title{
Slavs but Not Slaves: Slavic Migrations to South Italy in the Early and High Middle
} Ages

South Italy in the Early and High Middle Ages has been rightfully described as "a region open to a wide range of external, foreign influences". ${ }^{1}$ Beside the Langobards, Greeks and Normans, sources show the presence of Jews, Arabs, Armenians, Bulgarians, and others. ${ }^{2}$ Therefore it is hardly surprising to find among them also the inhabitants of the opposite, eastern Adriatic coast. However, in many cases the presence of these people from across the Adriatic was not voluntary. In fact, it has been generally established by the historians who deal with South Italy that most of the slaves mentioned in the documents from the mideleventh until the late twelfth century were Slavs by origin. The court of Bari even proclaimed in 1127 that no Christian men and women were to be held as slaves except those of Slavic origin. ${ }^{3}$ The argument that they were not (true) Christians, which was used from the thirteenth century onwards on both sides of the Adriatic coast as an excuse for enslavement of the (alleged) members of the Bosnian heretic Church, does not apply to this earlier period. It seems that the slaves of Slavic origin were too important for their owners to be discarded because of their religion. Most of these slaves were girls and women who were held as household servants in richer households in the coastal cities, in the same manner as it was the case in Dalmatia on the eastern Adriatic. The first slave-woman of Slavic origin has been attested as a part of a dower in Bari around 1057. A Dalmatian slave-girl owned by a nobleman from Siponto (in the southern part of the Gargano peninsula, nowadays a suburb of Manfredonia) was cured from leprosy at the shrine of St. Nicholas in Bari around 1100. ${ }^{5}$

And yet, these were not the only Slavs present in this period in South Italy, and their presence as plunderers and attackers, as well as settlers, has beeen noticed in historiography, most notably by André Guillou, Michele Fuiano, and Jean-Marie Martin. ${ }^{6}$ The earliest known

\footnotetext{
${ }^{1}$ Paul Oldfield, “The Iberian Imprint on Medieval Southern Italy,“ History, 93/311 (July 2008), 312.

2 André Guillou and Katia Tchérémissinoff, "Note sur la culture arabe et la culture Slave dans le katépanat d'Italie,“ Mélanges de l'École française de Rome: Moyen Áge - Temps Modernes 68 (1968): 677-692; André Guillou, "Italie méridionale byzantine ou Byzantins en Italie méridionale?" Byzantion - Revue internationale des Études Byzantines 44, fasc. 1 (1974): 153-158; Martin, La Pouille du VI au XII siècle (Rome: École Française de Rome, Palais Farnese 1993), 489-526.

${ }^{3}$ Codice diplomatico barese (hereafter cited as CDB), vol. 5, Le pergamene di S. Nicola di Bari, periodo normanno (1075-1194), ), ed. Francesco Nitti di Vito (Bari, 1902), doc. 74.

${ }^{4}$ CDB, vol. 4, Le pergamene di S. Nicola di Bari, periodo greco (939-1071), ed. Francesco Nitti di Vito (Bari, 1900), doc. 36, p. 76. More examples of slaves of Slavic origin are cited in: Paul Oldfield, City and Community in Norman Italy (Cambridge: Cambridge University Press, 2009), 206, n. 152.

${ }^{5}$ Pompeo Sarnelli quotes Vincent de Beauvais' Speculum historiale (XXV, cap. 38) in his Cronologia de' vescovi et arcivescovi sipontini (Manfredonia, 1680), 147-148; Martin, La Pouille, 509.

${ }^{6}$ André Guillou, "Migration et présence Slaves en Italie du $\mathrm{VI}^{\mathrm{e}}$ au XI $\mathrm{XI}^{\mathrm{e}}$ siècle," Zbornik radova Vizantološkog instituta 14-15 (1973): 11-16; Michele Fuiano, "La colonia slava di Devia nel corso del secolo XI," Congressi sulle relazioni tra le due sponde adriatiche, Rivista storica del Mezzogiorno 14 (1979): 39-52, also in Atti dell'
} 
presence of Slavs in South Italy is mentioned by Paul the Deacon in his History of the Langobards: in 642 some Slavs came with many boats and camped near Siponto, killing the local Langobard ruler and Duke of Benevento, Aio, in ambush. Afterwards they were outsmarted by Aio's blood-brother Radoald, son of Duke of Furlania (Friuli), who knew their language. ${ }^{7}$ It is unclear who these Slavs were and what were their intentions and motives for this attack. They may have been either Croats or Narentan Slavs, later notorious for their pirate abilities, or even coming from Hum - the area south of the Neretva river, yet it is less probable (as presumed by André Guillou) ${ }^{8}$ that these were the Avaro-Slavs persecuted by the Croats who, according to the Byzantine emperor Constantine Porphyrogenitus, were invited by Emperor Heraclius to fight against the Avars. ${ }^{9}$ There is a recent opinion that they might have crossed the sea in Slavic small boats, made from a single piece of wood (the monoxils), which were used in the sieges of Salonika and Constantinople in 614-616 and 626, ${ }^{10}$ although a recent crossing, undertaken by a modern expedition in traditional Narentan boats, proved quite difficult, even if possible. It is possible that the Slavs at Siponto may have been employed by the Byzantines who were interested in the town as an important port on the way leading from their possessions in Calabria towards Ravenna and Pentapolis. The expedition at Siponto took place in the beginning of the reign of Emperor Constans II, who showed exceptional interest in South Italy, more than any other Byzantine emperor since Justinian. ${ }^{11}$ In any case, since the Slavs were defeated by Radoald, settlement was no longer possible.

Another occasion for the appearance of Slavs in South Italy was the siege of Bari in 869-871. The city was in the hands of Arabs at the time and the Slavs from the eastern Adriatic coast participated in the siege as subjects of two emperors - Louis II of the Franks and Basileus I of Byzantium. ${ }^{12}$ However, it is more intriguing for our topic to consider the conquest of Siponto by rex Sclavorum Michael on 9 June 926, mentioned in the Annals of

Accademia di Scienze Morali e Politiche de Napoli 90 (1980): 8-14; Martin, La Pouille, 504-509. In Croatian historiography see: Zrinka Nikolić, "Najstarija slavenska naselja u južnoj Italiji“ (The oldest Slavic settlements in South Italy), in Raukarov zbornik, ed. Neven Budak, 75-82 (Zagreb: FF Press, 2005).

${ }^{7}$ Pauli Historiam Langobardorum, bk. IV, chap. 44, MGH SS rer. Germ, vol. 48, p. 170.

${ }^{8}$ Guillou, "Migration et présence Slaves en Italie du VI ${ }^{\mathrm{e}}$ au XI $\mathrm{I}^{\mathrm{e}}$ siècle," 15; Guillou and Tchérémissinoff, "Note sur la culture arabe et la culture Slave dans le katépanat d'Italie,“ 678.

${ }^{9}$ De administrando imperio (hereafter cited as DAI), ed. Gy. Moravcsik, transl. R. J. H. Jenkins (Budapest: 1949), 125, 143, 149.

${ }^{10}$ Mithad Kozličić, Hrvatsko brodovlje / Croatian shipping / Le navi croate, Eng. transl. by Maja Cambi, It. transl. by Ingrid Damiani Einwalter (Split: Književni krug; Zagreb: AGM, 1993), 45-47.

${ }^{11}$ For the Byzantines as instigators for this expedition see: Ivo Goldstein, Bizant na Jadranu (Byzantium on the Adriatic) (Zagreb: Latina et graeca, 1992), 146-148.

12 DAI, chap. 29, pp. 126-129. The use of Slavs on the Eastern Adriatic coast against the opponents of the Byzantine emperor, in this particular case by Leo III against the rebels in Sicily in 718, has been suggested by Tibor Živković: "The Strategos Paul and the Archontes of the Westerners,“ Byzantina Symmeikta 15 (2002): 161-176. 
Bari. ${ }^{13}$ King Michael can be identified as a ruler of Hum, the area between the Neretva river and the city of Dubrovnik - Michael, son of Višeta. Reasons for his attack are not altogether clear. Michael, son of Višeta, known in the Croatian and other South Slavic historiography as Michael Višević, is an interesting character, much neglected by the historiography dealing with the history of Southern Slavs, although he appears to have been an important figure at the Eastern Adriatic coast during the struggles of Byzantium against Simeon, emperor of the Bulgarians, in the first half of the tenth century. Constantine VII Porphyrogenitus was informed about his family stemming from the illustrious kindred of Litciki, from the old Slavic homeland - the area of the Vistula river in Poland. As a Byzantine ally/subject, he had received the titles of antipatos and patrikios. ${ }^{14}$ However, he was also known as an ally of the arch-enemy of Byzantium in that period - Simeon, emperor of the Bulgarians, whom he was supplying with intelligence ${ }^{15}$ and valuable hostages such as Peter, son of the Venetian doge Ursus II Particiacus ${ }^{16}$. It is possible that Michael's attack on Siponto was connected to his alliance with Simeon. Another possibility is that Michael, who appears to have been quite independent in his politics, changing sides as suited his interests, simply conducted the attack for the purpose of plundering, using the fact that the circumstances were unfortunate for the Byzantines. The attack was certainly well-timed, since the Langobard rulers were attacking Byzantine estates at the same time: Landulf of Capua and Benevento had invaded northern Apulia with the help of Spoleto, while the duke of Salerno, Guaimar II, had attacked the Byzantine estates in Lucania and Calabria. It took seven years for Byzantium to recover the lost estates. Finally, some scholars are of the opinion that Michael was actually recovering the city for the Byzantines after it had fallen into the hands of Atenulf, brother of Landulf of Capua, in $921 .{ }^{17}$ Whatever the reason for the attack, it does not seem likely that Michael had the idea of settling down in the area, as suggested by Guillou. ${ }^{18}$

\footnotetext{
${ }^{13}$ I used the critical edition by W. J. Churchill, "The Annales Barenses and The Annales Lupi Protospatharii: Critical Edition and Commentary“ (Ph. D. dissertation, Centre for Medieval Studies, University of Toronto, 1979): Anno 928. Hoc anno comprehendit Michael rex Sclauorum ciuitatem Sipontum mense julio, die sancte Felicitatis, secunda feria, indictione quintadecima, Annales Barenses, 116 . Anno $926^{\circ}$ Indictione $14^{\circ}$. Hoc anno comprehendit Michael sclauus Sipontum mense julii, Annales Lupi Protospatharii, 126. The latter date is considered to be the correct one by the editor.

${ }_{15}^{14}$ DAI, chap. 33, pp. 161-162.

15 Such as the meeting between the strategos of Dyrrachium, Leo Rhabduchus, and Serbian ruler, Peter Gojniković, in 917: DAI, chap. 32, p. 157.

16 According to Venetian chronicler John the Deacon, it was Michael, styled as dux Sclavorum, who captured the doge's son and handed him to Bulgarian king Simeon. This probably happened in 912 or 913: Giovanni Diacono, Istoria veneticorum, ed. and It. transl. by Luigi Andrea Berto (Bologna: Zanichelli Editore S.p. A., 1999) (hereafter cited as GD), bk. 3, chap. 40, p. 150.

${ }^{17}$ This was suggested by W. J. Churchill in his commentaries on the texts of the annals: "The Annales Barenses and The Annales Lupi Protospatharii,“201-202. See here also an overview of other opinions on the matter.

${ }^{18}$ Guillou, "Migration et présence Slaves en Italie du VI ${ }^{\mathrm{e}}$ au XI ${ }^{\mathrm{e}}$ siècle," 14.
} 
Why was it precisely Siponto, a city in the south of the Gargano peninsula, that was the target of both known Slavic invasions? A look at the map makes the reason rather obvious (map 1). Crossing between the two Adriatic coasts was most suitable at this spot and it had been used for these purposes since prehistoric times, as proved by the archaeological finds. ${ }^{19}$ It touched upon the central Dalmatian islands - Korčula (Gk. Korkyra Melaina, Lat. Corcyra Nigra, It. Curzola), Hvar (Gk. Pharos, Lat. Pharia, It. Lesina), Lastovo (Gk. Ladestanos, Lat. Augusta insula, It. Lagosta) and Palagruža (It. Pelagos) or Vis (Gk. Issa, Lat./It. Lissa), Biševo (It. Busi) and the island of Svetac (Engl. Saint, the full name of the island being St. Andrew) and the sole archipelagos in the west - the islands of Tremiti - on its way to the Gargano peninsula with its famous medieval shrine of Archangel Michael (San Michele de Monte Gargano). Advantages of this route were well known to the Byzantine emperor Constantine VII Porphyrogenitus, who wrote in his work De administrando imperio that "under the control of Dalmatia there is a close-set and very numerous archipelagos, extending as far as Beneventum, so that ships never fear to be overwhelmed in those parts“. ${ }^{20}$ Although in reality it cannot be said that the line of islands extends all the way to Benevento, it is true that the Adriatic islands come closest to the Italian coast in this area. Besides, it is here that the sea currents are perfectly suitable for the crossing. Old maps and archaeological excavations show that the western Adriatic coast was far more hospitable in this area concerning navigation and anchorage in the past than it is today, when in many parts it is sandy and flat (for example, the lake of Varano in the northern part of Gargano may have been only a gulf until the late sixteenth century). ${ }^{21}$ The crossing was particularly close to the land of the Narentan Slavs, who had settled in the area between the rivers Cetina and Neretva (Narenta) and the islands lying on the way to Italy. The Gargano peninsula is only 105 kilometres away from the island of Lastovo. Constantine Porphyrogenitus claimed that the Narentans did not rule over the islands of Vis and Lastovo in the tenth century, ${ }^{22}$ but it is certain that they possessed them some 50 years later. ${ }^{23}$ Slavic population had already settled

\footnotetext{
${ }^{19}$ Maria Cecilia d'Ercole, "Itinerari e scambi nell' Adriatico preromano (VIII-V sec. A. C.)," in Les Routes de l'Adriatique antique géographie et économie, eds. Slobodan Čače, Anamarija Kurilić, Francis Tassaux, 91-106 (Bordeaux: Ausonius éditions; Zadar: Presses Universitaires de Zadar, 2006); Mithad Kozličić, Mateo Bratanić, "Ancient Sailing Routes in Adriatic," in Les Routes de l'Adriatique antique géographie et économie, eds. Slobodan Čače, Anamarija Kurilić, Francis Tassaux, 107-124 (Bordeaux: Ausonius éditions; Zadar: Presses Universitaires de Zadar, 2006).

${ }^{20}$ DAI, chap. 29, p. 139.

${ }^{21}$ D'Ercole, "Itinerari e scambi“; Kozličić and Bratanić, “Ancient Sailing Routes in Adriatic“.

${ }^{22}$ DAI, chap. 36, p. 165.

${ }^{23}$ GD, bk. 4, pp. 186-194.
} 
on these islands. The navigation route towards the Italian coast was also convenient for the inhabitants of Hum, subjects of Michael Višević.

Therefore, it is not too surprising that, if we look for the possible traces of Slavic settlement in Italy, we find them on the Gargano peninsula (Monte Gargano), mentioned in several documents from the cartulary of the monastery of St. Mary on the islands of Tremiti. ${ }^{24}$ These documents deal with the estates in the surroundings of the abandoned church of St. Mary de calena on Gargano, which belonged to the Tremiti monastery. There are some undoubtedly Slavic names appearing in four of the eleventh-century documents. The first one, dated to July 1023, mentions an estate that Leo, archbishop of Siponto, bought for the monastery of St. Mary on Tremiti from Stane Gypto, filius Lilii; a piece of land purchased from Maleša (Malexha), Većanego (Benckanego), and son of Nežedrag (filii Nesscedragi) and Lastaka, son of Milstrimir (Lastaka filius Milstrimiro), another that he bought from Gajdavit (Gaidavito), Negočaj (Negazzai), Vitadrag (Vittadrago) and son of Strijadrag (fi(lio) Striadragi), and eventually one obtained from the aforementioned Gajdavit. All these estates were in the surroundings of the abandoned church of St. Mary. ${ }^{25}$ In another document from June 1043, a priest called Skypizo and his brother Lupulo, sons of Sberanja (Skypizo et Lupulo viri germani, filii Sberagni) from the area of the city (civitas) of Devia, sold a piece of land to Leo, provost of the monastery of St. Mary, which at that time was a cella of St. Mary on Tremiti. Most probably this was the same church that was mentioned in the document from 1023, only restored in the meantime. The transaction was performed in the presence of iupanus (Cr. župan) Andrew and other good people. In the company of Leo, there was an advocate of St. Mary called Sarian (or Strian as Barada has read it, which appears more Slavic). The price was a ram in the value of 3 miliarii. ${ }^{26}$ In the third document from March 1053, Tripo, son of Stefaničelo, together with George, son of Mihalj, and Tahamir, son of Trepac (Tripo, filius Stephanicelco et Georgi filius Michali et Tachamiro filius Trepazzi) from the area of castello Peschici (Pesclizzo), donated for the sake of their souls their own church of St. Mary in the area called Calenella minor (probably called so in order to differentiate it from St. Mary de Calena), with some vineyards and people who belonged to the church, to the

\footnotetext{
${ }^{24}$ Armando Petrucci, ed., Codice diplomatico del Monastero benedettino di S. Maria di Tremiti (1005-1237) (hereafter cited as Tremiti), vol. 1-3, in: Fonti per la storia d'Italia 98 (Rome: Istituto storico italiano per il medioevo, 1960). Before this edition, some of the documents concerning Slavic names were also transcribed by Miho Barada, a leading Croatian paleographer, and later edited by Branimir Gušić in "Naše primorje (historijsko-geografska studija)“ (Our littoral - a historical-geographical study), Pomorski zbornik 1 (Zagreb: Jugoslavenska akademija znanosti i umjetnosti, 1962): 19-65, esp. 51-53, n. 398. Some Slavic names in Barada's transcription appear somewhat different than in Petrucci's.

${ }^{25}$ Tremiti, doc. 8, p. 26.

${ }^{26}$ Tremiti, doc. 32, pp. 101-104.
} 
monastery of St. Mary by the sea (in the document from 1023 St. Mary de Calena), near Devia. This was done in the presence of iupanus (župan) of castello Devia, Ljubico (Glubizzo), and other good people. These good people mentioned at the end of the document next to the iupanus were Lačla (Laccla or Baccla as Barada has read it), Sarian (Sariano or Strian in Barada's version), and Iban, son of Polkanj (Ibani fi(lii) Polcagni). Mihalj, son of Braccla (Michali filius Braccla), is mentioned as a middleman ${ }^{27}$ In the October of the same year, the same župan Ljubico was present when a certain Sarian, son of Drobanj (Sariano filio Drobagna, perhaps the one mentioned in the last document as a witness), gave to the monastery of St. Mary on Tremiti half of his house, a vineyard, two boats, and four pieces of land on his death-bed. Among his neighbours, the document mentions Simon, son of Ibac, perhaps Ivač (Simeoni filius(!) Ibazza), Draia (Draža?), son of Radavit (Draia filius(!) Radavitti), and Draia, son of Ibanic, perhaps Ivanić (Draia filius(!) Ibanizi), as well as an estate that belonged to certain Beleš (Belesci). ${ }^{28}$ In March 1054, Ljubico, Iban (most probably Ivan - Slavic for John), and Lačla are mentioned again. Together with some other people, they offered some land to the church of St. Mary. However, now there was also a certain Count Robert, son of Constans, de genere Normannorum, who was the senior and dominator of the city of Devia. Ljubico is most probably the man who was called iupanus in the previous document. ${ }^{29}$ Some of these names appear at the same time among the Croats and other Slavs of the Eastern Adriatic, e.g. Ljubac (Glubaz), Većenego (Vekenego), Negočaj (Negozai), Strian, etc. ${ }^{30}$ So, judging by these documents, it can be established that in the first half of the eleventh century there were at least two settlements with entirely or predominantly Slavic population. These settlements were termed castrum or castellum, which could at that time mean a fortified village or perhaps a small town. The more important one was Devia - a castrum or castellum, sometimes appearing even as civitas, situated between the lakes of Lesina and Varano. Today it no longer exists, but another one does - thirty kilometers from Devia - the castellum called Peschici (map 2). It is especially important that a župan (iupanus) is mentioned as the head of Devia, since that title denoted a Slavic official - usually the head of the county. This shows a certain kind of self-governance. Peschici was most likely also under the rule of župan from Devia. The first documented župan was Andrew (1043),

\footnotetext{
${ }^{27}$ Tremiti, doc. 47, pp. 150-153.

${ }^{28}$ Tremiti, doc. 48, pp. 153-156.

${ }^{29}$ Among the donors, there are Gluvizzo, filius Nicola et Ibano filius Polcagni et Laccla filius Sinogla et Urso filius Belcangco et Cosma filius Ibano Albo: Tremiti, doc. 51, pp. 159-163.

${ }^{30}$ Codex diplomaticus regni Croatiae, Dalmatiae et Slavoniae, eds. Jakov Stipišić and Miljen Šamšalović (Zagreb: Jugoslavenska akademija znanosti i umjetnosti, 1967) (hereafter CDCDS), doc. 35, p. 52; doc. 98-99, pp. 132-133; doc. 136, p. 177; doc. 156, p. 196.
} 
followed by Ljubico (1053). They must have been under the sovereign rule of Byzantium, since in 1043 a turmarch is mentioned in the area, an official of a lesser rank than strategos in the Byzantine theme. In October 1054, Devia fell into the hands of the Normans, since Count Robert was now mentioned as its senior and dominator. He was subjected to Walter, the son of Amicus, who ruled Lesina by the lake of the same name. ${ }^{31}$ It is interesting that twenty years later (1074), one of Walter's sons, Amicus II, would undertake an expedition to Dalmatia in an attempt of conquering it, and during that enterprise he would take the Croatian king as prisoner. ${ }^{32}$ It is possible that Amicus, in his desperate attempt at creating a better position for himself in the area, which was at that time dominated by his cousin, Duke Robert Guiscard, ${ }^{33}$ became interested in the Eastern Adriatic as a consequence of his contacts with the Slavs in the area dominated by his family. Since in 1054 Count Robert appears with the former župan Ljubico and his people as the donor of the church of St. Mary by the sea at Devia, it seems that the relations between the Norman lords and the local community were not hostile, but the Norman conquest nevertheless meant the end of Slavic self-rule at Gargano. The title of župan is not mentioned in this document or afterwards.

Who were these Slavs and when did they settle at Monte Gargano? Andre Guillou considered their settlement as a consequence of the already mentioned intervention of Michael Višević in 926, which he explained as a result of the occupation of Michael's land by the Bulgarian emperor Simeon. Since Constantine VII Porphyrogenitus named them Serbs, Guillou also considered them as such, ${ }^{34}$ and in another article he even stated that they may have been fugitives from Rascia, perhaps fleeing from Simeon in the first quarter of the tenth century. ${ }^{35}$ Some Serbs (the ruling family included) are known to have come to Croatia while fleeing before Simeon at that time, but there is no evidence that any of them crossed or intended to cross the Adriatic. ${ }^{36}$ Branimir Gušić raised the question whether the Gargano settlers may have arrived there in the tenth century, and this is also the time-period suggested by Ferdo Gestrin, a Slovenian scholar who has written extensively about the Slavic settlement

\footnotetext{
${ }^{31}$ Graham A. Loud, The Age of Robert Guiscard: Southern Italy and the Norman Conquest (Harlow: Longman, 2000), 101.

${ }^{32}$ CDCDS, docs. 107-108, pp. 136-139. About Amicus' Dalmatian enterprise see: Francesco Babudri, "Il conte Amico di Giovinazzo: la sua impresa adriatica e la marineria apulo-normanna," Archivio storico pugliese 12 (1959): 103-137.

${ }^{33}$ Loud, The Age of Robert Guiscard, 235, 237-241.

${ }^{34}$ Guillou, "Migration et présence Slaves en Italie du VI ${ }^{\mathrm{e}}$ au XI ${ }^{\mathrm{e}}$ siècle," 14-15; Guillou and Tchérémissinoff, "Note sur la culture arabe et la culture Slave dans le katépanat d'Italie," 678.

35 "Italie méridionale byzantine ou Byzantins en Italie méridionale," 157-158.

${ }^{36}$ DAI, cap. 32, p. 159.
} 
in South Italy in the Late Middle Ages. ${ }^{37}$ Jean-Marie Martin has argued that the settlers were more probably Narentan Slavs and not those of Hum, since the islands dominated by the Narentans are closest to the Gargano coast. In his opinion, the migration was a consequence of the raid undertaken by the Macedonian-Bulgarian ruler Samuel (Samuilo) along the eastern Adriatic coast, while previous Slavic invasions of the Italian coast had left no trace. ${ }^{38}$ Eventually, it should be mentioned that the seventeenth-century scholar Pompeo Sarnelli left a note that the villages of Vico and Peschici were founded by Slavs who, under the command of Sueripolo Capitano, defeated the Saracens invading Gargano in 970. They were invited by Emperor Otto I, who afterwards rewarded them with land on the peninsula. ${ }^{39}$

I would suggest yet another possible occasion for settlement, which is chronologically closest to the actual traces of the Gargano Slavs in the documents. These are the Venetian expeditions at the time of Doge Peter II Orseolo (991-1009), directed against the Croats and other Slavs of the Eastern Adriatic. Since the Croatian ruler threatened the Venetians, the doge sent six ships under the command of Badovarius Bragadinus, who conquered the town called Issa and brought captives of both sexes with him to Venice. ${ }^{40}$ The island of Issa (Cr.Vis, It. Lissa), with its main settlement of the same name, comes to mind as the first candidate for the expedition of Badovarius Bragadinus. Could the men and women of Issa have been the Slavic people who later settled on the Gargano peninsula, visited by the doge's navy a few years afterwards? However, the equation of Vis with Issa has been challenged because at that period the island was not under the rule of a Croatian prince. ${ }^{41}$

In any case, the conquest of Issa increased the hostilities between the Venetians and the Slavs, which led to the great naval expedition of Doge Peter II Orseolo (ca. 1000) on the pretext of freeing his subjects from paying tribute to the Slavs - along the Istrian and

\footnotetext{
${ }^{37}$ Gušić, "Naše primorje," 51; Gestrin, "Migracije Slovanov v Italijo. Rezultati Jugoslavanske historiografije“ (Migration of Slavs to Italy: Results of Yugoslav Historiography), Zgodovinski časopis 32/1-2 (1978), 10.

${ }^{38}$ La Pouille, 505-506.

${ }^{39}$ Cronologia de' vescovi et arcivescovi sipontini, 111. Gerhard Rohlfs, "Ignote colonie slave sulle coste del Gargano," Mélanges linguistiques offerts a Emil Petrovici, in: Cercetări de linguistică 3 (1958), 413, n. 2. With the exemption of Rohlfs, none of the aforementioned scholars mentions Sarnelli's version. It is uncertain if this is Sarnelli's construction or perhaps based on some sources, or both.

${ }^{40}$ Circa haec namque tempora Croatorum iudex propter interdictum sibi censum a duce in Veneticos lesionis molestiam exercere conatus est. Unde domnus dux sex naves praeparatas illuc mittens, quibus Badovarius, cognomento Bragadinus, prefuit. Qui unam illorum civitatem, quae Issa nominabatur, conprehendens utriusque sexus captivos ad Veneciam deportavit.: GD, bk. 4, chap. 40, p. 184.

${ }^{41}$ Therefore Chissa on the island of Pag has been suggested, and generally accepted, as the possible candidate: Jadran Ferluga, L'amministrazione bizantina in Dalmazia (Venice: Deputazione di storia patria per le Venezie, 1978), 195; Lujo Margetić, "Le cause della spedizione veneziana in Dalmazia nel 1000," Histria et Adriatica: Raccolta di saggi storico-giuridici e storici (Centro di ricerche storiche di Rovigno - Collana degli Atti 6) (Lint, Trieste, 1983), 243.
} 
Dalmatian coast. ${ }^{42}$ The only substantial resistance was put up by the improbi inhabitants of the island of Lastovo, who according to the contemporaries were notorious pirates. Finally, the doge succeeded in destroying their fortified centre, forcing the survivors to swear that they would give up piracy in the future. ${ }^{43}$ As mentioned before, the island of Lastovo is only about 100 kilometres away from Peschici and it is the closest of all Dalmatian islands to the western Adriatic coast. It is not impossible that the survivors of Lastovo, after the destruction of their fort, settled at the relatively nearby western Adriatic coast or were settled there by the doge in order to make sure they would not continue with their pirate activities. Doge Peter Orseolo had connections to this part of South Italy as well. Namely, the Venetian navy helped to liberate the Byzantine town of Bari from the Saracen siege in 1002. This expedition is commemorated by a graphito in a cave on the little island near Vieste on Gargano. ${ }^{44}$ Since the doge had mobilised Dalmatian men into his navy during his expedition to Dalmatia two years before, it is possible that some of them were among the settlers of Gargano as well. Nowadays, it is generally accepted that the Orseolo expedition along the Eastern Adriatic coast was agreed to by the Byzantine authorities, since Byzantium suffered from severe struggles with the Bulgarian emperor Samuel (Samuilo) at the time. Cooperation between the Byzantines and the Venetians can be seen in the liberation of Bari in 1002. ${ }^{45}$ Perhaps one could also consider the settlement of Slavs on the Gargano peninsula as a part of the

\footnotetext{
42 The main source for the Orseolo expedition along the eastern Adriatic coast that involved Istrian and Dalmatian towns is his secretary, John the Deacon: GD, bk. 4, pp. 186-194. About the expedition see: Venezia e la Dalmazia: anno Mille - secoli di vicende comuni, Atti del convegno di studio, Venezia, 6 ottobre 2000, ed. Nedo Fiorentin (Treviso: Canova; Venice: Regione del Veneto, 2002).

${ }^{43}$ Preterea dum isdem dux quicquid cordi aderat Deo fautore ad votum consequeretur, improbos Ladestinê insulae habitatores agredi conatus est. A quorum rabiae Venetici illa per navigantes loca propriis facultatibus privati, nudi sepissime evaserunt. Erat siquidem eadem insula scopulosis promunctoriis circumsepta; licet aditum intrantibus non denegaret, montium tamen sublimitate ostentabatur, e quibus unus murorum menibus turriumque hedificiis munitus, inexpugnabilis ab omnibus credebatur.

[54] Dein vero predictus princeps, multitudine navium collecta, quendam illius insulae portum penetravit, mandans civibus ut relicta pertinatia ad se venirent, aut pugna sese petituros scirent. Qui timore constricti pacifica verba protulerunt. Postmodum illis iniunctum fuit nulla ratione pacem a duce consequi posse, nisi civitatem ipsi destruerent, destructam vero inreparabilem inhabitabilemque relinquerent. Quod omni nisu facere interdicentes, tanti exercitui sese obsistere adorsi sunt. Tunc isdem princeps suos ad certamen preparare illosque inpugnare acriter iussit; verum quia arduus locus difficilem dabat appropinquantibus ingressum, iaculorum ictibus hostes aliquandiu procul, virtute qua poterant, coarcere satagebant. Tamen Dei omnipotentis dispensacione maior pars exercitus ex illo loco, unde illius municionis ostia patebant, impetum facientes, reliqua montis per devia consendendo, turres, ubi aquarum vascula tuebantur, comprehenderunt. In quibus consistentes, in tantum luctamine comprimebant, donec deiecti animo, armis depositis, nichil amplius quam mortis exosum periculum evadere flecsxis exorabant poplitibus. Dux itaque pietatis amator omnes vivos conservare instituens, civitatem tantum devastare precepit: GD, bk. 4, chap. 53-54, pp. 193-194.

${ }^{44}$ Giorgio Ortalli, "Pietro II Orseolo, dux Veneticorum et Dalmaticorum," in: Venezia e la Dalmazia. Anno Mille, 24-27.

${ }^{45}$ Ortalli, "Pietro II Orseolo, dux Veneticorum et Dalmaticorum," 13-27.
} 
Byzantine policy, an attempt at strengthening the defences in the area which was only acquired by them in the last decades of the tenth century. ${ }^{46}$

Connection with the Narentans can be seen in another document preserved in the cartulary of the monastery on Tremiti. It is a donation made by a certain priest and monk John, son of Gaudius, called Hrlac, from Split (Iohannes, presbiter et monachus, filius cuiusdam Gaudii, qui supra nomen Cherlicco uocatur, de ciuitate Spalato). ${ }^{47}$ John built a church dedicated to St. Silvester on the small island of Biševo near Vis, and in the 1050s decided to offer himself and his donation to the monastery of Tremiti with the acceptance and in the presence of rex or iudex Marianorum Berigoj. Although Gouillou connected this title to the place called Varano at Gargano, ${ }^{48}$ it is the title held by the ruler of the Narentans or perhaps the Narentan islands. The presence of a Narentan ruler on Tremiti and the connection with the monastery might point to a link with the settlers of Gargano as well. The church still exists in Biševo, and archaeological excavations in the 1990 revealed a man's grave before the main altar. It may be the founder, priest John, whose memorial plate with an inscription (MEMENTO DNE IOHS PPO) was found as a spolium in the renovated church (photograph).

The already-mentioned documents from the Tremiti monastery show that the settlers mixed with the local population, accepting their customs. For instance, the aforementioned documents show that the settlers' wives had a right to one-fourth of their husbands' possessions, in accordance with the Langobard law of Morgengabe (the morning gift). ${ }^{49}$ Names in the documents show a mixture of Slavic and local features. On the other hand, Martin, author of an immense monograph on Puglia, has mentioned the use of rams as a means of payment as a unique case in the entire region. He has also noticed the presence of joint ownership by brothers and cousins among the mentioned Slavs. Some Slavic names appear in places such as Rignano (Malgerius de Radeslavo, 1183) and Vico del Gargano. Martin is of the opinion that these Slavic names may have simply been in fashion for a while ${ }^{50}$ but it is more likely that they were preserved as a consequence of name-inheriting patterns. Due to the intermarriage with other peoples of South Italy, the Slavs seem to have been assimilated by the twelfth century. In Vieste of $1152 / 1153$, there is a mention of a man

\footnotetext{
${ }^{46}$ Loud, The Age of Robert Guiscard, 32-33.

${ }^{47}$ Tremiti, doc. 42, pp. 134-135; CDCDS, doc. 58, p. 78-79.

${ }^{48}$ Guillou, "Migration et présence Slaves en Italie du VI ${ }^{\mathrm{e}}$ au XI ${ }^{\mathrm{e}}$ siècle," 14-15; Guillou, "Italie méridionale byzantine ou Byzantins en Italie méridionale?," 157; Guillou and Tchérémissinoff, "Note sur la culture arabe et la culture Slave dans le katépanat d'Italie," 678; Fuiano, "La colonia slava di Devia nel corso del secolo XI," 43. Martin corrected the mistake made by Guillou and Fuiano: La Pouille, 505, n. 97.

${ }^{49}$ Tremiti, doc. 32, p. 103; doc. 47, p. 151.

${ }^{50}$ La Pouille, 507-508.
} 
called Robertus Sclavus as a legal representative of the monastery on Tremiti - an interesting mixture of Norman and Slavic heritage. ${ }^{51}$

Slavic traces are also visible in place names on the Gargano peninsula. First of all, there is the name of the littoral village of Peschici (castellum Pesclizzo in 1053) - whose literal meaning would be "small sands", which is in accordance with the geological appearance of the area. The even more important settlement of Lesina, mentioned in 1023, is connected with the Slavic name of the Dalmatian island of Hvar, which derives from the Slavic word les - forest. ${ }^{52}$ This connection between the name of the island and the settlement on Gargano was pointed out by an expert in languages and dialects spoken in South Italy, Gerhard Rohlfs. While studying the Garganic dialects in the 1940s and 1950s, he recognized about 17 words of Slavic origin, especially in the aforementioned Peschici, but also in some other nearby places, such as San Giovanni Rotondo or Vico. For example, the Croatian word skakavac - grasshopper - is almost identical with Garganic scazcavázzo, while some others show traces of Slavic - such as the words for little girls (ciúrcia $=$ Cr. curica), worm (langlistə $=$ Cr. glista), different kinds of lizards $($ vúschərə, salambachə $=$ Cr. gušter , zelembać), the coast, the snail (pugghiáca $=\mathrm{Cr}$. puž), etc. There are even differences in pronunciation in different parts of Gargano: skirt (Cr. suknja) is pronounced sciúcchə in Peschici, sciáuchə in Vico, sciúcchələ in San Giovanni Rotondo. According to Rohlfs, who was not acquainted with the historical sources that mention Slavs in the eleventh century at the time he identified these words, changes that the words had gone through show that they must be older than the dialect of the region of Molise, which is spoken by the descendants of Croatian refuges who fled from Ottoman raids in the fifteenth and sixteenth centuries. ${ }^{53}$ It is interesting that the early Slavic traces on Gargano survived for a long time although the assimilation of eleventh-century settlers had already been completed by the end of the twelfth century, and despite the later arrivals of refugees at the time of the Ottoman invasions in the fifteenth and sixteenth centuries. ${ }^{54}$ That the place name Peschici belongs to the time of earlier

\footnotetext{
${ }^{51}$ Guillou, “Italie méridionale byzantine ou Byzantins en Italie méridionale?” 157; Tremiti, doc. $106,107$.

${ }^{52}$ It is quite peculiar that the Italian name of the island is Lesina, which derives from the Slavic word for wood les or lesna, while the Croatian name is Hvar, which comes from the name of Greek colony Pharos, under the Roman rule Pharia or later Fara.

${ }^{53}$ Gerhard Rohlfs, "Ignote colonie slave sulle coste del Gargano," 409-413. About the Molisan Croats and their dialect see: Sime do simena / Il seme dal seme / Sjeme od sjemena, ed. Antonio Sammartino (Montemitro: Fondazione "Agustina Piccoli," 2006).

${ }^{54}$ All these latemedieval settlers are sometimes called the Molisan Croats, for example by the Jesuit Jakov Mikalja (Giacomo Micaglia, Jacobus Micalia, John son of Michael), a native of Peschici (1600 -+Loreto, 1654). Mikalja was the author of Blago jezika slovinskoga / Thesaurus lingua illyricae, which contains the first Italian grammar in the Croatian language as well as a Slavic-Latin-Italian dictionary, considered to be the first published dictionary of Croatian. He was almost certainly a descendant of refugees from the Eastern Adriatic
} 
Slavic settlement has also been recognised by the Croatian linguist Petar Šimunović. ${ }^{55}$ By the seventeenth century, the mixture of two traditions - one of the speakers of the dialect with old Slavic influences in Vico and Peschici (at that time certainly stronger than at the time of Rohlfs' studies), and another of the more recent settlers who fled from the Ottoman danger appeared in the version recorded by Pompeo Sarnelli, which may indicate that Slavs in Vico and Peschici descended from the fighters against the Saracens.

The traces of early Slavic presence can be found in place names in the areas surrounding Gargano as well - for example, a Via Sclavenesca appears in 1093 in Castellum Novum in the western part of the diocese of Troia. Terra qui vocat castellutzo de ipsi Dalmatini is mentioned in Balsignano in Bari as early as $962^{56}$, as well as Lama de Sclavis in Terlizzi in $1153,1155,1220 .^{57}$ As has already been mentioned, there are also traces of Slavic onomastics in Bari, Rignano, Vico del Gargano, Vieste. As a consequence of the nameinheriting patterns, these names could endure for a long time after the assimilation and the disappearance of Slavic identity. San Vito degli Schiavoni or degli Schiavi, which is mentioned in the fourteenth century near Brindisi, changed its name into San Vito dei Normanni only in 1860 . There are some hints that the Slavs had also settled in the counties of Abruzzi and Molise, which in the later Middle Ages would receive far more numerous immigration from the opposite coast. The earliest traces in place names can be found in the area of Trivento (around Chieti) at the end of the tenth century, as well as later, in the twelfth century - Rocca de Sclavis on the coast, contrada Sclavorum and Fons de Slavia in 1203 in the territory of Termoli, etc. ${ }^{58}$

The presence of Slavic settlers can be observed in other regions of South Italy in the High Middle Ages. Sixty Slavs were foot-soldiers in the company of Robert Guiscard at the beginning of his career in Calabria in the late 1040s and early 1050s, at the time when he was merely one of the Norman war-lords trying to make his fortune in South Italy. The importance

coast who fled before the Ottomans and not of the early-medieval settlers. In his dictionary, he mentions Pještica as a Slavic name for Peschici (Lat. Pescutium). This is another Slavic dialect, which Mikalja took as a standard for his dictionary and which is also today the standard Croatian language. About Mikalja see: Vladimir Horvat, "I lessicografi gesuiti del Seicento tra le due sponde: Bartol Kašić-Cassius-Cassio (Pag, 1575-1650, Roma) e Jakov Mikalja-Mica(g)lia (Peschici, 1601-1654, Loreto)," in Homo adriaticus - identità culturale e autocoscienza attraverso $i$ secoli, Atti del convegno internazinale di studio organizzato dalla Accademia Marchigiana di Scienze e Lettere ed Arti, Ancona, 9-12 novembre 1993, eds. Nadia Falaschini, Sante Graciotti , Sergio Sconocchia, 105-116 (Reggio Emilia: Diabasis, 1998).

${ }_{55}^{55}$ Hrvatska prezimena (Croatian surnames) (Zagreb: Golden marketing, 1995), 366, n. 83.

${ }^{56} \mathrm{CDB}$, vol. 4, doc. 2, p. 5.

${ }^{57}$ CDB, vol. 3, Le pergamene della cattedrale di Terlizzi (971-1300), ed. Francesco Carabellese (Bari, 1899), doc. 71, p. 92, doc. 73, p. 94, doc. 207, p. 226. See also: Martin, La Pouille, 508, n. 126.

${ }^{58}$ Davide Aquilano, "Insediamenti, popolamento e commercio nel contesto costiero abruzzese e molisano (sec. XI-XIV): Il caso di Pennaluce,” Melanges de l'école française de Rome Moyen Age 109/1 (1997): 59-130, esp. 72. 
of these men for the Norman leader can be seen in the testimony of monk and chronicler Geoffrey Malaterra, who wrote that "by giving them gifts and promising them even more in the future, he had practically transformed them into brothers, so loyal were they to him. ${ }^{\text {(59 }}$ After checking their loyalty in one nocturnal ambush, Robert Guiscard advanced them from foot-soldiers into chivalry. Military skill and strength of the Slavic settlers is also mentioned in Sicily in 1079, when they threatened the life of Robert's brother, Duke Roger, during his siege of Taormina. ${ }^{60}$ Since in both of these occasions the Slavs acted as military units, this may indicate that their numbers were not insignificant in these regions, although there are no preserved sources that would offer information on their settlements or possible selfgovernment. The most significant Slavic participant in the Norman conquest of South Italy in the second half of the eleventh century would have been (or is at least judged as such by some historians of South Italy because of his name) Gradilon, brother-in-law of the Norman leader Abelard de Hauteville, who participated in a rebellion against Abelard's uncle, Duke Robert Guiscard. He was blinded and castrated as a punishment for his involvement in the rebellion of 1079, albeit Robert spared most of the other Norman participants. ${ }^{61}$ Perhaps the reason for Gradilon's fate was the fact that he belonged to the "natives" of the land rather than the Norman kin.

Nevertheless, despite these interesting observations on the Slavic presence in South Italy, it is only the Garganic community that presents some evidence of a self-governance, as well as remnants in the local dialect that have survived into our century. This could mean that the eleventh-century settlement of Slavs at Gargano was more significant than the mere handful of documents mentioning them may suggest. The presence of župan shows that it was an organized and compact community, which is another indication supporting the hypothesis that they came or were brought there as a group rather than individual settlers. This again might point to the island of Lastovo as a possible place of origin of the Gargano Slavs.

In conclusion: the presence of Slavs on western Adriatic coast can be ascertained quite soon after the settlement on the eastern shore, although the sources speak only of isolated war

\footnotetext{
59 ...invenire posse Guiscardus usque ad sexaginta, quos Sclavos appelant, totius Calabriae gnaros, secum habens, quos quasi fratres fidelissimos sibi benefactis et majoribus promissis effecerat ...De Rebus Gestis Rogerii Calabriae et Siciliae Comitis et Roberti Guiscardi Ducis fratris eius auctore Gaufredo Malaterra,ed. Ernesto Pontieri, Rerum Italicarum Scriptores (Bologna: Niccolo Zanichelli, 1927²), chap. 16, p. 16; transl. in : Goffrid Malaterra, The deeds of Count Roger of Calabria and Sicily and of his brother Duke Robert Guiscard, transl. Kenneth Baxter Wolf (Ann Arbor: The University of Michigan Press, 2005), 63; Loud, The Age of Robert Guiscard, 111.

${ }^{60}$ The deeds of Count Roger of Calabria..., chaps. 1.16, p. 64; 3.15, p. 146.

${ }^{61}$ Guillaume de Pouille. La Geste de Robert Guiscard, ed. and transl. by Marguerite Mathieu (Palermo: 1961), bk. 2, pp. 192, 198; Loud, The Age of Robert Guiscard, 242-243.
} 
campaigns. Nevertheless, toponomastic and onomastic traces indicate the presence of Slavs in a wider area of South Italy, and for the beginning of the eleventh century we can even talk of organized colonization (most likely of the Narentan Slavs) at Gargano, which resulted in at least two castella - Devia and Peschici - with a predominantly Slavic population, governed by a župan. Their self-government ended with the arrival of the Normans in 1054, which probably contributed to the already ongoing assimilation. 